\title{
Zinc Inhibits TRPV1 to Alleviate Chemotherapy-Induced Neuropathic Pain
}

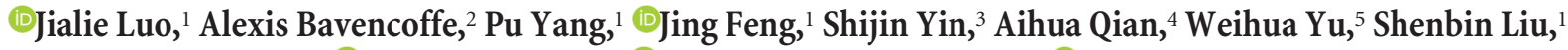 \\ Xuan Gong, ${ }^{1}$ Tao Cai, ${ }^{1}$ Edgar T. Walters, ${ }^{2}{ }^{-}$Carmen W. Dessauer, ${ }^{2}$ and ${ }^{\circledR}$ Hongzhen $\mathrm{Hu}^{1}$ \\ ${ }^{1}$ Center for the Study of Itch, Department of Anesthesiology, Washington University School of Medicine, St. Louis, Missouri 63110, ${ }^{2}$ Department of \\ Integrative Biology and Pharmacology, University of Texas Health Science Center at Houston, Houston, Texas 77030, ${ }^{3}$ College of Pharmacy, South-Central \\ University for Nationalities, Wuhan, Hubei 430073, China, ${ }^{4}$ Department of Gastroenterology, Ruijin Hospital, Shanghai Jiaotong University, Shanghai \\ 200240, China, and ${ }^{5}$ Department of Anatomy, Chongqing Medical University, Chongqing 400016, China
}

Zinc is a transition metal that has a long history of use as an anti-inflammatory agent. It also soothes pain sensations in a number of animal models. However, the effects and mechanisms of zinc on chemotherapy-induced peripheral neuropathy remain unknown. Here we show that locally injected zinc markedly reduces neuropathic pain in male and female mice induced by paclitaxel, a chemotherapy drug, in a TRPV1-dependent manner. Extracellularly applied zinc also inhibits the function of TRPV1 expressed in HEK293 cells and mouse DRG neurons, which requires the presence of zinc-permeable TRPA1 to mediate entry of zinc into the cytoplasm. Moreover, TRPA1 is required for zinc-induced inhibition of TRPV1-mediated acute nociception. Unexpectedly, zinc transporters, but not TRPA1, are required for zinc-induced inhibition of TRPV1-dependent chronic neuropathic pain produced by paclitaxel. Together, our study demonstrates a novel mechanism underlying the analgesic effect of zinc on paclitaxel-induced neuropathic pain that relies on the function of TRPV1.

Key words: neuropathic pain; paclitaxel; TRPA1; TRPV1; zinc

\section{Significance Statement}

The chemotherapy-induced peripheral neuropathy is a major limiting factor affecting the chemotherapy patients. There is no effective treatment available currently. We demonstrate that zinc prevents paclitaxel-induced mechanical hypersensitivity via inhibiting the TRPV1 channel, which is involved in the sensitization of peripheral nociceptors in chemotherapy. Zinc transporters in DRG neurons are required for the entry of zinc into the intracellular side, where it inhibits TRPV1. Our study provides insight into the mechanism underlying the pain-soothing effect of zinc and suggests that zinc could be developed to therapeutics for the treatment of chemotherapy-induced peripheral neuropathy.

\section{Introduction}

Chemotherapy-induced peripheral neuropathy (CIPN), a highly debilitating symptom without effective treatment, affects $>50 \%$ of patients undergoing treatment with commonly used chemotherapy drugs, including paclitaxel, vincristine, and oxaliplatin (Addington and Freimer, 2016). The painful neuropathy usually

\footnotetext{
Received June 29, 2017; revised Oct. 24, 2017; accepted Nov. 16, 2017.

Author contributions: E.T.W., C.W.D., and H.H. designed research; J.L., A.B., P.Y., J.F., and H.H. performed research; J.L., S.Y., A.Q., W.Y., S.L., X.G., T.C., and H.H. analyzed data; J.L. and H.H. wrote the paper.

This work was supported in part by National Institutes of Health Grants R01RGM101218 and R01DK103901 to H.H., and Center for the Study of Itch, Department of Anesthesiology, Washington University School of Medicine to H.H. We thank Gina Story (Washington University, St. Louis) for providing the TRPA1 K0 mice.

The authors declare no competing financial interests.

Correspondence should be addressed to Dr. Hongzhen Hu, Center for the Study of Itch, Department of Anesthesiology, Washington University School of Medicine, 660 South Euclid Avenue, Box 8054, St. Louis, M0 63110-1093. E-mail: huh@anest.wustl.edu.

DOI:10.1523/JNEUROSCI.1816-17.2017

Copyright $\odot 2018$ the authors $\quad 0270-6474 / 18 / 380474-10 \$ 15.00 / 0$
}

leads to dose reduction or discontinuation of the treatment, resulting in poor treatment outcomes. Currently, how chemotherapies with certain drugs cause pain and neuropathy is not well understood, which has severely limited the development of effective pain therapies (Hershman et al., 2014; Miltenburg and Boogerd, 2014). Therefore, it is critical to understand the molecular and cellular mechanisms underlying the pathogenesis of CIPN to develop effective and safe therapeutics for the treatment of CIPN.

Pain results from complex processing of neural signals at different levels. Transient receptor potential (TRP) channels are molecular sensors for noxious mechanical, chemical, and thermal insults. Activation of peripheral nociceptors by TRP channels, especially the capsaicin receptor TRPV1 and wasabi receptor TRPA1, initiates neurogenic inflammation and pain sensation (Caterina et al., 2000; Lee et al., 2005; Bautista et al., 2006; Huang et al., 2008). TRPV1 is expressed in nearly $60 \%$ of peptidergic small-diameter primary nociceptors in the dorsal root ganglia (DRG) and trigeminal ganglia, which sense environmental cues 
in the skin and many visceral organs (Xu et al., 2013). TRPV1 is a nonselective cation channel that is activated by capsaicin, noxious heat, acid, and many endogenous ligands as well as plantderived natural compounds. In addition to direct activation, TRPV1 is also sensitized by activation of GPCRs and tyrosine kinase receptors through intracellular signal transduction pathways involving activation of many protein kinases, including protein kinase $\mathrm{C}$ (PKC), protein kinase $\mathrm{A}$ (PKA), and phosphoinositide 3-kinase (PI3K). Both activation and sensitization of TRPV1 lead to enhanced pain responses. Both genetic ablation and pharmacological inhibition studies have provided convincing evidence that TRPV1 significantly contributes to both chronic inflammatory pain and neuropathic pain resulting from peripheral nerve injury. Moreover, both TRPV1 and TRPA1 have been shown to be involved in the pathogenesis of CIPN (BoyetteDavis et al., 2015).

Zinc is an essential metal that has been extensively used to promote wound healing in humans for almost 3000 years (Lansdown et al., 2007). It acts as an anti-inflammatory agent and soothes pain sensation in a number of model systems (Safieh-Garabedian et al., 1996; Larson and Kitto, 1999; Liu et al., 1999; Nozaki et al., 2011). Zinc is present in the spinal cord and DRG neurons, including small-diameter nociceptive neurons (Velázquez et al., 1999; Koeppen et al., 2013). Indeed, depletion of vesicular zinc in the spinal cord dorsal horn enhances neuropathic pain in mice (Jo et al., 2008). Moreover, zinc-deficient mice have increased prostaglandin $\mathrm{E}_{2}$ levels and sensitized nociceptive $\mathrm{C}$ fibers, suggesting that endogenous zinc might exert a tonic inhibition on nociception (Izumi et al., 1995). Furthermore, centrally applied zinc attenuates neuropathic pain in mouse models of peripheral neuropathy (Liu et al., 1999; Nozaki et al., 2011) and clinical studies (Pastorfide et al., 1989; Zekavat et al., 2015). However, it is not known whether exogenously applied zinc in the periphery can affect CIPN.

In the present study, we show that local application of zinc inhibits mechanical hypersensitivity induced by paclitaxel treatment in mice in a dose-dependent manner. The zinc-induced analgesic effect is severely attenuated in TRPV1-deficient mice. Extracellular zinc application inhibits capsaicin-evoked intracellular calcium $\left(\left[\mathrm{Ca}^{2+}\right]_{i}\right)$ responses and membrane depolarization in a subset of mouse DRG neurons, and locally injected zinc inhibits capsaicin-evoked acute nociceptive behaviors. Moreover, zinc inhibits capsaicin-induced $\left[\mathrm{Ca}^{2+}\right]_{i}$ responses and membrane current intracellularly, and the zinc-sensitive TRPA1 is required for the inhibition of TRPV1 by extracellular zinc. Surprisingly, zinc transporters, but not TRPA1, are required for inhibition of paclitaxel-induced chronic neuropathic pain by zinc. Together, our data demonstrate that TRPV1-mediated pain sensations are inhibited by extracellular zinc entering the cells through either TRPA1 channels or zinc transporters under acute and chronic settings.

\section{Materials and Methods}

Animals. Male and female C57BL/6J mice (The Jackson Laboratory), congenic TRPV1 knock-out (KO) (The Jackson Laboratory), and congenic TRPA1 KO mice at the age of 7-10 weeks were used in this study. The TRPA1 KO mice on the C57BL/6J background were described previously (Cruz-Orengo et al., 2008). All animal care and experimental procedures were in accordance with the animal care and use protocol approved by the Institutional Animal Care and Use Committee of University of Texas Health Science Center at Houston and the Institutional Animal Care and Use Committee at Washington University School of Medicine in St. Louis. All studies involving animals are reported in accordance with the ARRIVE guidelines for reporting experiments involving animals (McGrath et al., 2010). Mice were housed in a temperature $\left(24^{\circ} \mathrm{C}\right)$ - and humidity $(40 \%-50 \%)$-controlled environment on a $12: 12 \mathrm{~h}$ dark-light cycle with free access to food and water. All experiments were performed blind with respect to genotypes and treatments.

Paclitaxel treatment and von Frey test. Paclictaxel (TSZ Chem) was administered at a dose of $4 \mathrm{mg} / \mathrm{kg}$ intraperitoneally on days $0,2,4$, and 6 as illustrated in Figure $1 \mathrm{~A}$ according to previous studies (Matsumoto et al., 2006). Mechanical allodynia was measured as the hindpaw withdrawal response to von Frey hair stimulation using the up-and-down method as described in our previous study (Yin et al., 2013). Intraplantar injection of zinc acetate ( $\mathrm{ZnAc}$ ) (Sigma-Aldrich) was performed on day 7 following the von Frey test.

Intrathecal delivery of siRNA. To knockdown the ZIP family of zinc transporters (ZIPs), the siRNAs specific for mZIP3, mZIP6, and mZIP7 and the siRNA Universal Negative Control were purchased from SigmaAldrich, and $0.5 \mathrm{nmol}$ of each was prepared in PBS and mixed with polyethylenimine. After 15 min incubation at room temperature, the mixture was injected intrathecally into mice anesthetized with isoflurane. Animals were used $3 \mathrm{~d}$ after the final intrathecal injection.

Cell culture and transfection. HEK293 cells were obtained from ATCC in 2010 and have been tested to confirm lack of mycoplasma contamination; however, no additional authentication has been performed. Cells were grown as a monolayer using passage numbers $<30$ and maintained in DMEM (Invitrogen), supplemented with 10\% FBS (Invitrogen), 100 units $/ \mathrm{ml}$ penicillin and $100 \mu \mathrm{g} / \mathrm{ml}$ streptomycin in a humidified incubator at $37^{\circ} \mathrm{C}$ with $5 \% \mathrm{CO}_{2}$. The cells were transiently transfected with complementary DNA for mouse TRPV1 (mTRPV1), human TRPA1 (hTRPA1), and hTRPA1-D915A mutant using Lipofectamine 2000 (Invitrogen) with a ratio of $0.3: 1$. After transfection, cells were maintained in DMEM at $37^{\circ} \mathrm{C}$ for $24 \mathrm{~h}$ before use. The hRPA1-D915A mutant was made using the QuikChange II XL mutagenesis kit (Agilent Technologies), according to the manufacturer's directions and confirmed by DNA sequencing.

Retrograde labeling of paw-innervating DRG neurons. Mice were anesthetized with isoflurane, and $10 \mu \mathrm{l}$ of $1,1^{\prime}$-dilinoleyl-3,3,3',3'-tetramethylindocarbocyanine, 4-chlorobenzenesulfonate (FAST DiI) $(10 \mathrm{mg} / \mathrm{ml}$ in methanol) was injected into the paws of paclitaxel-treated mice. To prevent leakage and labeling of adjacent tissues, the needle was left in place for $30 \mathrm{~s}$ after each injection, and any leaked dye was removed with a cotton swab. DRG neurons were isolated $5 \mathrm{~d}$ after DiI injection.

Isolation and culture of DRG neurons. Mice were killed by cervical dislocation following $\mathrm{CO}_{2}$ asphyxia. Spinal columns were removed and placed in ice-cold HBSS; neurons were acutely dissociated and maintained as described previously (Hu et al., 2009). In brief, laminectomies were performed and bilateral DRG or lumbar DRG of DiI-injection side were dissected out. After removal of connective tissues, DRG were transferred to a $1 \mathrm{ml} \mathrm{Ca}{ }^{2+} / \mathrm{Mg}^{2+}$-free HBSS containing $2 \mu \mathrm{l}$ saturated $\mathrm{NaHCO}_{3}, 0.35 \mathrm{mg} \mathrm{L}$-cysteine, and $20 \mathrm{U}$ papain (Worthington), and incubated at $37^{\circ} \mathrm{C}$ for $15 \mathrm{~min}$. The suspension of DRG was centrifuged, and the pellet was incubated in $1 \mathrm{ml} \mathrm{Ca}{ }^{2+} / \mathrm{Mg}^{2+}$-free HBSS containing $4 \mathrm{mg}$ collagenase Type II and $1.25 \mathrm{mg}$ dispase Type II (Worthington) at $37^{\circ} \mathrm{C}$ for $15 \mathrm{~min}$. After digestion, neurons were pelleted, resuspended in Neurobasal medium containing 2\% B-27 supplement, 1\% L-glutamine, 100 units $/ \mathrm{ml}$ penicillin plus $100 \mu \mathrm{g} / \mathrm{ml}$ streptomycin, and $50 \mathrm{ng} / \mathrm{ml}$ nerve growth factor, plated on a $12 \mathrm{~mm}$ coverslip coated with poly-L-lysine $(10 \mu \mathrm{g} / \mathrm{ml})$, and cultured under a humidified atmosphere of $5 \% \mathrm{CO}_{2} /$ $95 \%$ air at $37^{\circ} \mathrm{C}$ for $18-24 \mathrm{~h}$ before use.

Patch-clamp recording. Whole-cell patch-clamp recordings were performed using an EPC 10 USB amplifier (HEKA Elektronik) at room temperature $\left(22^{\circ} \mathrm{C}-24^{\circ} \mathrm{C}\right)$ on the stage of an inverted phase-contrast microscope equipped with a filter set for green and red fluorescence visualization. Pipettes pulled from borosilicate glass (BF 150-86-10; Sutter Instruments) with a Sutter P-97 pipette puller had resistances of 2-4 $\mathrm{M} \Omega$ when filled with pipette solution containing the following (in $\mathrm{mM}$ ): 140 CsCl, 1 EGTA, $1 \mathrm{MgCl}_{2}$, and $10 \mathrm{HEPES}, \mathrm{pH} 7.4$, and $315 \mathrm{mOsm} / \mathrm{L}$. Cells were continuously perfused with extracellular solution containing the following (in mM): $140 \mathrm{NaCl}, 5 \mathrm{KCl}, 2 \mathrm{CaCl}_{2}, 1 \mathrm{MgCl}_{2}, 10$ glucose, and 10 HEPES, pH adjusted to 7.4 with $\mathrm{NaOH}$, and the osmolarity was adjusted to $\approx 340 \mathrm{mOsm} / \mathrm{L}$ with sucrose. The whole-cell membrane currents were recorded using voltage ramp from -100 to $100 \mathrm{mV}$ for $500 \mathrm{~ms}$ at holding 
potential of $0 \mathrm{mV}$. For inside-out patch-clamp recordings, both the pipette solution and bath solution contained the following (in $\mathrm{mM}$ ): 140 $\mathrm{CsCl}, 1 \mathrm{EGTA}, 1 \mathrm{MgCl}_{2}, 10 \mathrm{HEPES}, \mathrm{pH}$ 7.4. For current-clamp recording, the pipette solution contained the following (in $\mathrm{mM}$ ): $140 \mathrm{KCl}, 1 \mathrm{MgCl}_{2}$, 1 EGTA, 10 HEPES, and 5 ATP, pH 7.4, and 315 mOsm/L. Data were acquired using PatchMaster software (HEKA Elektronik). Currents were filtered at $2 \mathrm{kHz}$ and digitized at $10 \mathrm{kHz}$. Data were analyzed and plotted using Clampfit 10 (Molecular Devices). Values are given as mean \pm SEM; $n$ indicates the number of measurements.

Calcium imaging. Cultured DRG neurons were loaded with $4 \mu \mathrm{M}$ Fura-2 AM (Invitrogen) in culture medium at $37^{\circ} \mathrm{C}$ for $60 \mathrm{~min}$. Cells were then washed three times and incubated in HBSS at room temperature for $30 \mathrm{~min}$ before use. Fluorescence at 340 and $380 \mathrm{~nm}$ excitation wavelengths was recorded on an inverted Nikon Ti-E microscope equipped with 340 and $380 \mathrm{~nm}$ excitation filter wheels using NISElements imaging software (Nikon). Fura-2 ratios (F340/F380) were used to reflect changes in intracellular $\mathrm{Ca}^{2+}$ upon stimulation. Values were obtained from 100 to 250 cells in time-lapse images from each coverslip. For FlexStation assays, HEK293 cells transfected with TRPV1 were plated in 96-well plate and maintained for $24-48 \mathrm{~h}$ before use. Cells were loaded with Fluo-4 according to the manufacturer's protocol, washed again, and placed on FlexStation 3 (Molecular Devices) to measure fluorescence increase upon addition of agonist in the absence or presence of different zinc compounds as described previously (Luo et al., 2011).

Quantitative RT-PCR. Total RNA was extracted from mouse DRG using the RNeasy kit (QIAGEN) according to the manufacturer's instructions. In brief, the mouse DRG were collected and homogenized. A total of $1 \mu \mathrm{g}$ RNA was treated with DNase I (Invitrogen), and the cDNA was synthesized in vitro using ThermoScript RT-PCR System kit (Invitrogen). The real-time PCR was conducted following the protocol for Fast SYBR Green Master Mix kit (Applied Biosystems) in the StepOnePlus Real-Time PCR System (Applied Biosystems) with primers presented in Table 1 . The expression levels of ZIPs were normalized to GAPDH using the $2^{-\Delta \mathrm{CT}}$ method.

Nocifensive behavior. Each mouse was placed individually in clear Plexiglas chambers $(8 \times$ $8 \times 12 \mathrm{~cm}$ ) and acclimated for at least $1 \mathrm{~h}$ to the testing environment before all experiments. To measure pain-related behaviors, the left hindpaws of mice were injected intraplantarly with $10 \mu \mathrm{l}$ vehicle $(0.9 \%$ saline $+5 \%$ DMSO + $0.5 \%$ o Tween 80 ; Sigma-Aldrich) with or without chemicals. The protocol for chemicals injection was represented in Figures $1 A, E$, and $5 B$. Time spent on nocifensive behavior (flicking and licking injected paw) was recorded for 5 min.

Experimental design and statistical analysis. Both male and female mice were used in this study. All data are presented as mean \pm SEM for $n$ independent observations. Statistical analysis was performed using GraphPad Prism 5.0 software. Unpaired Student's $t$ test was used to analyze statistical significance between two groups (see Figs. $1 E, 4 A-D, 5 E, H$, and $6 C$ ). One-way ANOVA was used where more than two groups were compared (see Figs. 2C,D, $3 B, C)$. Repeated-measures ANOVA was used to compare differences between multiple groups occurring over time (Figs. $1 B-D, 5 A$, and $6 B$ ). The post hoc Bonferroni test was per-
Table 1. Primer sequences used for the measurement of ZIPs in mouse DRG with real time $\mathrm{RT}^{\mathrm{P}} \mathrm{PR}^{a}$

\begin{tabular}{lllc}
\hline Name & Forward $\left(5^{\prime} \rightarrow 3^{\prime}\right)$ & Reverse $\left(5^{\prime} \rightarrow 3^{\prime}\right)$ & Length $(\mathrm{bp})$ \\
\hline mZIP1 & TGCTTGTGTCCTGGTCTTCTC & ACAGGCTGACTGCCAGAATG & 140 \\
mZIP2 & AGCCGCTGGCACGTTTTTATA & ACCCAGCAGCCACACAGCTA & 104 \\
mZIP3 & TGTCAGCTTCTCCTATGGCTTGT & GGATCCGGCCTGCACTAATA & 64 \\
mZIP4 & TCTGAGAAAGATGGGCCTTGTAG & TGTTGGACTGTGGAGATTG & 89 \\
mZIP5 & TCCAGTGGCCTCAGCACTA & AGCAGCTTCCGAAAGGATAA & 107 \\
mZIP6 & ACAGGGATATTCATGGGCATTA & AACCAGAGCGACATACATGAACAAG & 90 \\
mZIP7 & TGCTGCCTGAGCTATTGAGAGA & AATCAGTACCATCATGGCAACAC & 92 \\
mZIP8 & AACAATTGCCTGGATGATCAC & CAAAGTACAAGATGCCCCAATC & 82 \\
mZIP9 & TAAGAGCAGTAAAGAAGCCCTTTCA & ACGGTGGCAACATAAAGAAATC & 90 \\
mZIP10 & GCCCTTCACCAGAGACCAATAA & CCTCCTGACCTTCACTGACTTCA & 65 \\
mZIP11 & CTCACCTGGGTGCTACAGAAGAC & CAATGCAGGGTCCAAGTTCA & 62 \\
mZIP12 & AATGTGCCAGCCTCCAACA & TTACTAGGCCATCTGCAAAATTGTG & 100 \\
mZIP13 & TGCTTGCCAACACCATAGACAAC & CAGAAGCCCGATCTTTTGC & 83 \\
mZIP14 & TCTGCCAGGAGGATGAGAAG & ATAATGGAGAAGCCGGTTAGG & 85 \\
mGAPDH & AGGTCGGTGTGACGGATTTG & TGTAGACCATGTAGTTGAGGTCA & 100 \\
\hline
\end{tabular}

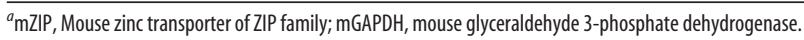
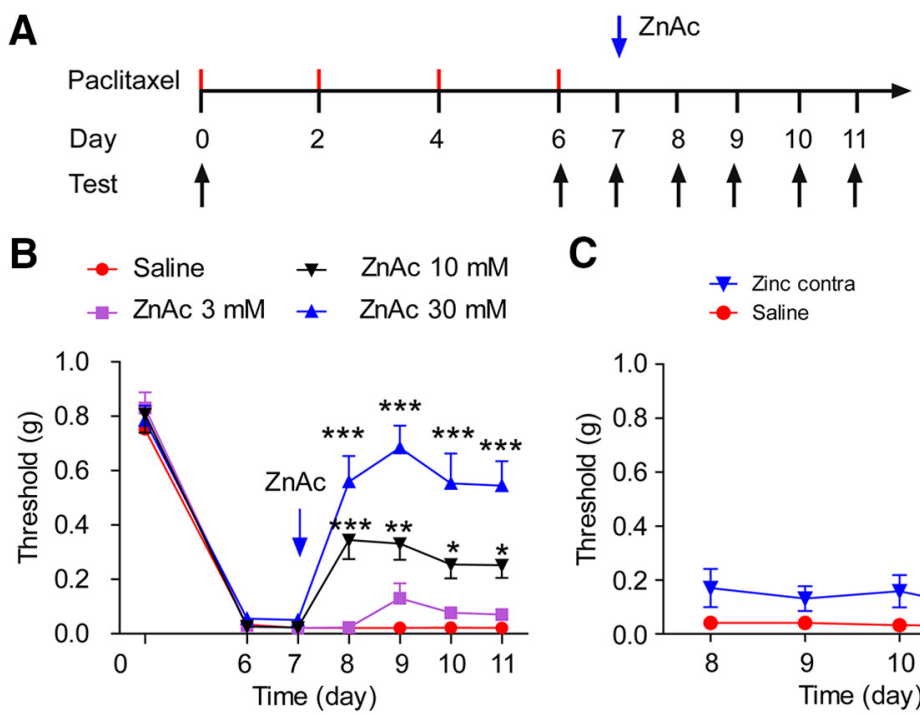

D
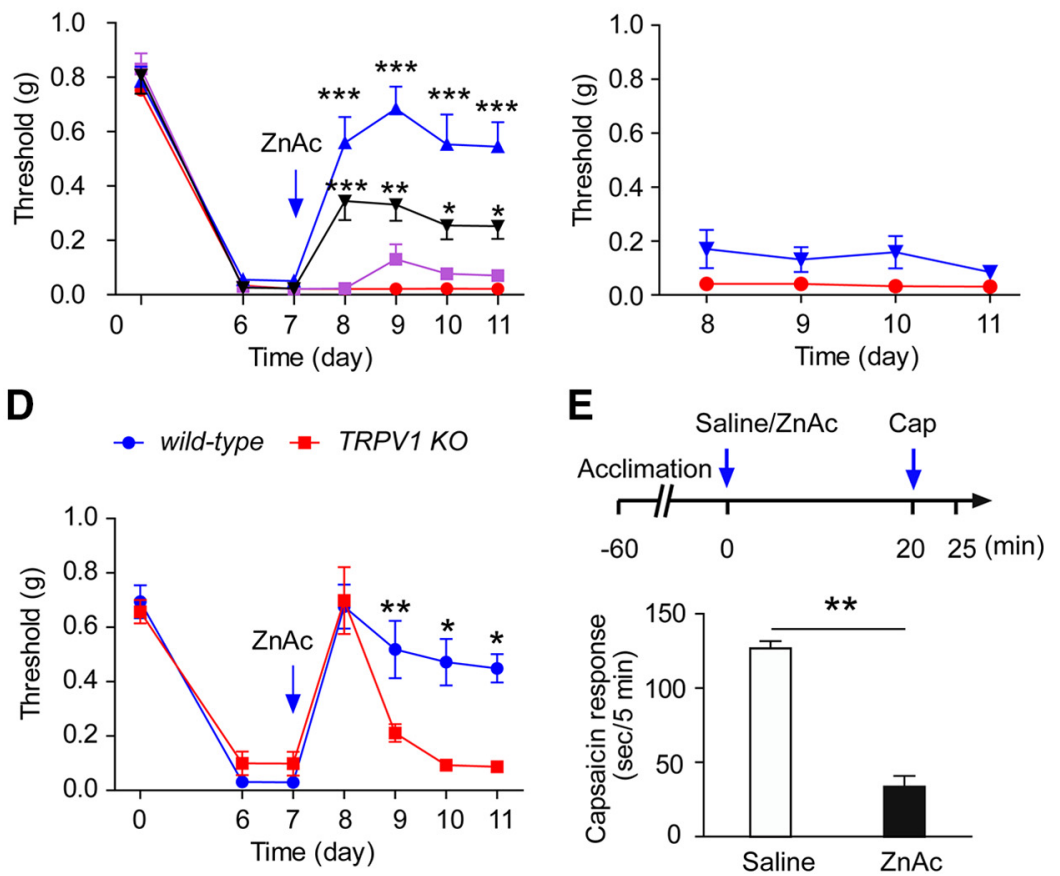

Figure 1. Zinc inhibits paclitaxel-induced mechanical hypersensitivity in a TRPV1-dependent manner. $A$, Schematic protocol of induction of mechanical hypersensitivity by paclitaxel and administration of zinc. Paclitaxel $(4 \mathrm{mg} / \mathrm{kg})$ was administered through intraperitoneal injections at days $0,2,4$, and $6 . \operatorname{ZnAc}(3,10$, or $30 \mathrm{~mm}, 10 \mu \mathrm{l})$ was injected into the plantar of paclitaxel-treated mice at day 7 . Black arrows indicate the dates when von Frey tests were performed. $\boldsymbol{B}$, Dose- dependent inhibition of paclitaxel-induced mechanical hypersensitivity by ZnAc. ${ }^{*} p<0.05$ versus saline group (repeated-measures ANOVA). ${ }^{* *} p<0.01$ versus saline group (repeated-measures ANOVA). ${ }^{* * *} p<0.001$ versus saline group (repeated-measures ANOVA). $n=5$ mice in each group. $C$, Time courses show the hypersensitivity induced by paclitaxel in the contralateral paws of $\mathrm{ZnAC}$ - and saline-injected mice. $n=5$ mice in each group. $D$, Time courses represent the effect of $Z n A$ c on paclitaxel-induced mechanical hypersensitivity in both wild-type ( $n=$ 7 mice) and TRPV1 KO ( $n=5$ mice) mice. ${ }^{*} p<0.05$ versus wild-type group (repeated-measures ANOVA). ${ }^{* *} p<0.01$ versus wild-type group (repeated-measures ANOVA). $\boldsymbol{E}$, Top, Schematic protocol of ZnAc inhibition of capsaicin-elicited acute nocifensive responses. Bottom, Bar chart represents the inhibition ofZnAc on capsaicin $(0.5 \mu \mathrm{g}, 10 \mu \mathrm{l})$-induced acute nociception. ${ }^{* *} p<0.01$ versus saline group (Student's $t$ test). $n=7$ mice for saline; and $n=6$ mice for $Z n A c$. 
A

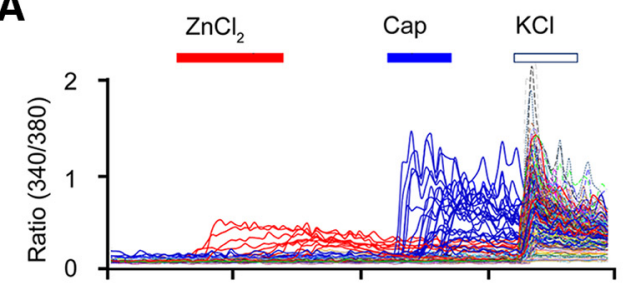

B

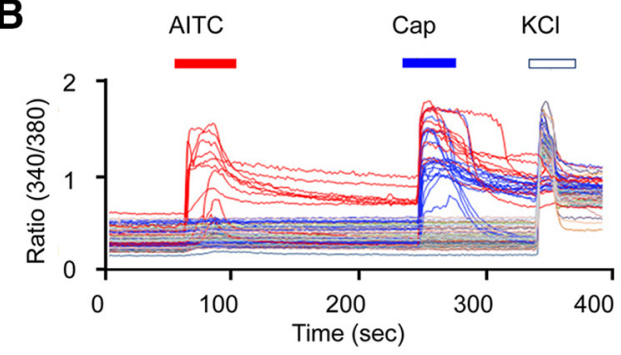

C

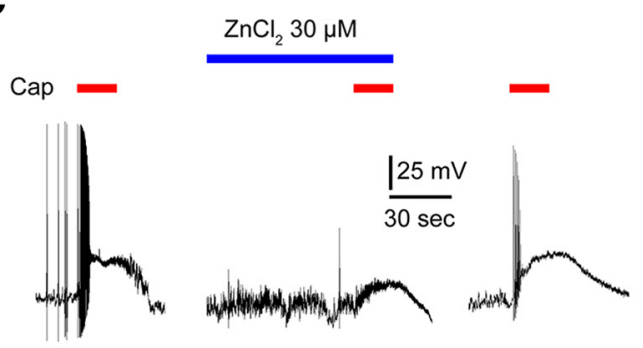

D

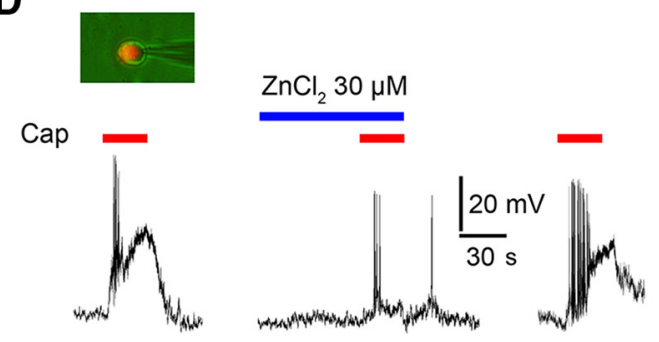

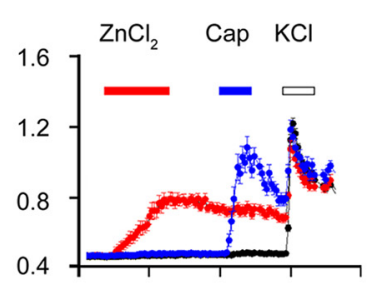
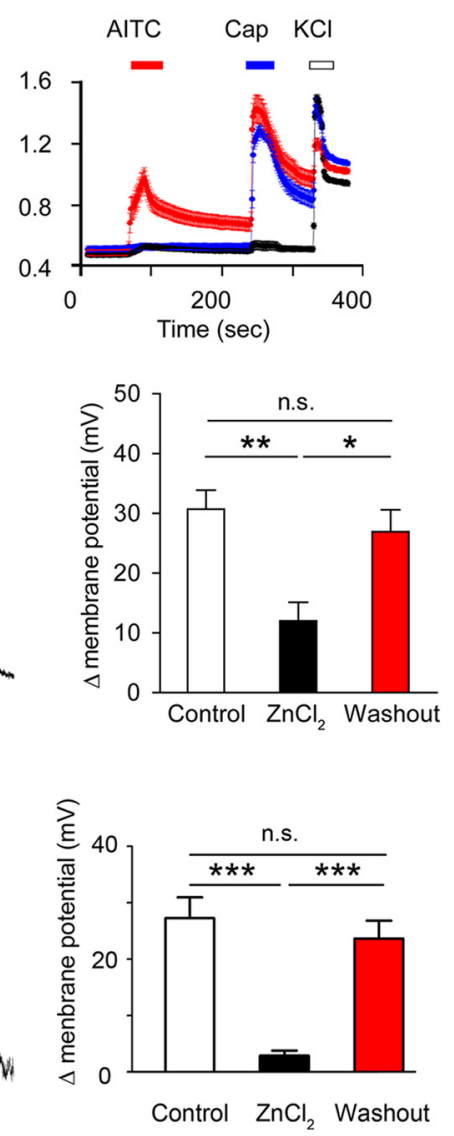

Figure 2. Zinc inhibits capsaicin-induced $\left[\mathrm{Ca}^{2+}\right]_{i}$ response in a subset of DRG neurons. $A$, Ratiometric $\mathrm{Ca}^{2+}$ imaging of cultured wild-type mouse DRG neurons. Each trace corresponds to fluorescence in a single neuron. Neurons were exposed to $30 \mu \mathrm{M} \mathrm{ZnCl}_{2}$, $1 \mu \mathrm{m}$ capsaicin, and $100 \mathrm{~mm} \mathrm{KCl}$ for the indicated times (colored bars). Red represents zinc-responsive neurons, which showed no response to subsequent capsaicin application. Blue represents zinc-insensitive neurons, which responded to subsequent capsaicin application. The remaining traces were recorded from the zinc- and capsaicin-insensitive cells. Right, Averaged responses of the three subsets of DRG neurons. $B, \mathrm{Ca}^{2+}$ imaging of wild-type DRG neurons, exposed to $100 \mu \mathrm{m}$ AITC, $1 \mu \mathrm{m}$ capsaicin, and $100 \mathrm{~mm}$ $\mathrm{KCl}$ for the indicated times. Red represents AITC-responsive cells, which responded to subsequent capsaicin application. Blue represents AITC-insensitive neurons, which also responded to subsequent capsaicin application. The remaining traces indicate the AITC- and capsaicin-insensitive neurons. Right, Averaged responses of the three subsets of DRG neurons. C, Representative traces and summarized data showing capsaicin-induced membrane depolarization and action potential firing before (left), during (middle), and after (right) the application of zinc in an untreated wild-type mouse DRG neuron. Horizontal bars represent the indicated time course of chemical applications. n.s., Not significant versus control group. ${ }^{*} p<0.05$ versus washout group (ANOVA). ${ }^{*} p<$ 0.01 versus control group (ANOVA). $n=7$ cells in each group. $\boldsymbol{D}$, Representative traces and summarized data showing the effect of $\mathrm{ZnCl}_{2}$ on capsaicin-induced membrane depolarization and action potential firing in a Dil-labeled DRG neuron from a paclitaxeltreated mouse. Inset, Representative picture of the Dil-labeled DRG neuron in which the voltage traces in D were recorded. n.S., Not significant versus control group. ${ }^{* *} p<0.001$ versus control and washout group (ANOVA). $n=6$ cells in each group.

formed following ANOVA analysis. A $p$ value of $<0.05$ was considered significantly different.

\section{Results}

Zinc inhibits paclitaxel-induced mechanical hypersensitivity in a TRPV1-dependent manner

Chemotherapy-induced neuropathic pain is a major dose-limiting adverse effect in cancer chemotherapy, and lacks effective treat-

ments. Because zinc is used to soothe pain and has shown promising effects in attenuating neuropathic pain caused by peripheral nerve injury (Liu et al., 1999; Nozaki et al., 2011), we explored the possibility that zinc might attenuate paclitaxel-induced mechanical hypersensitivity by applying $\mathrm{ZnAc}$ to the paw of paclitaxeltreated mice through intraplantar injections. After four paclitaxel injections (Fig. $1 A)$, mice developed mechanical allodynia, which was markedly attenuated by administration of $\mathrm{ZnAc}$ in a dose-dependent man$\operatorname{ner}\left(F_{(3,96)}=54.24, p<0.0001\right.$; Fig. $\left.1 B\right)$. Moreover, the effect of $\mathrm{ZnAclasted}$ for $>4 \mathrm{~d}$ after a single injection (Fig. $1 B$ ). On the other hand, ZnAc did not significantly inhibit paclitaxel-induced hypersensitivity of contralateral paws $\left(F_{(1,24)}=3.42, p=0.101\right.$; Fig. $1 C)$, suggesting that $\mathrm{ZnAc}$ mainly exerts the inhibitory effect locally. Previous studies have demonstrated that enhanced expression and function of TRPV1 are tightly correlated with paclitaxel-induced mechanical hypersensitivity, suggesting that targeting TRPV1 for inhibition could be a novel approach for alleviating chemotherapy-induced neuropathic pain (Anand et al., 2010; Chen et al., 2011; Hara et al., 2013; Li et al., 2015; Sisignano et al., 2016). We thus sought to determine whether inhibition of paclitaxelinduced mechanical hypersensitivity by zinc is related to the inhibition of TRPV1 function. The data showed that the zinc-induced sustained inhibitory effect was markedly attenuated in TRPV1 $\mathrm{KO}$ mice compared with wild-type mice $\left(F_{(1,60)}=9.56, p=\right.$ 0.011 ; Fig. $1 D)$. It should be noted that TRPV1 deficiency did not abolish the analgesic effect of zinc within the first $24 \mathrm{~h}$ after zinc administration, which suggests that TRPV1-independent pathways are involved in the early phase of zinc inhibition of paclitaxel-induced neuropathic pain. These results suggest that TRPV 1 is critically involved in zincinduced analgesic effect in paclitaxelinduced neuropathic pain. Furthermore, when we applied ZnAc 20 min before intraplantar injections of capsaicin (Fig. $1 E)$, the capsaicin-induced acute nocifensive behaviors were also substantially reduced $\left(t_{(14)}=5.43, p=0.002\right.$; Fig. $\left.1 E\right)$. Together, these results suggest that zinc inhibits both acute and chronic pain sensations mediated by TRPV1.

Extracellular zinc inhibits capsaicin response in DRG neurons

To elucidate the cellular basis of the inhibitory effect of zinc on TRPV1, we compared capsaicin-evoked $\left[\mathrm{Ca}^{2+}\right]_{i}$ response in cultured mouse DRG neurons with and without pretreatment of $\mathrm{ZnCl}_{2}$ (Sigma-Aldrich). Upon administration of extracellular 

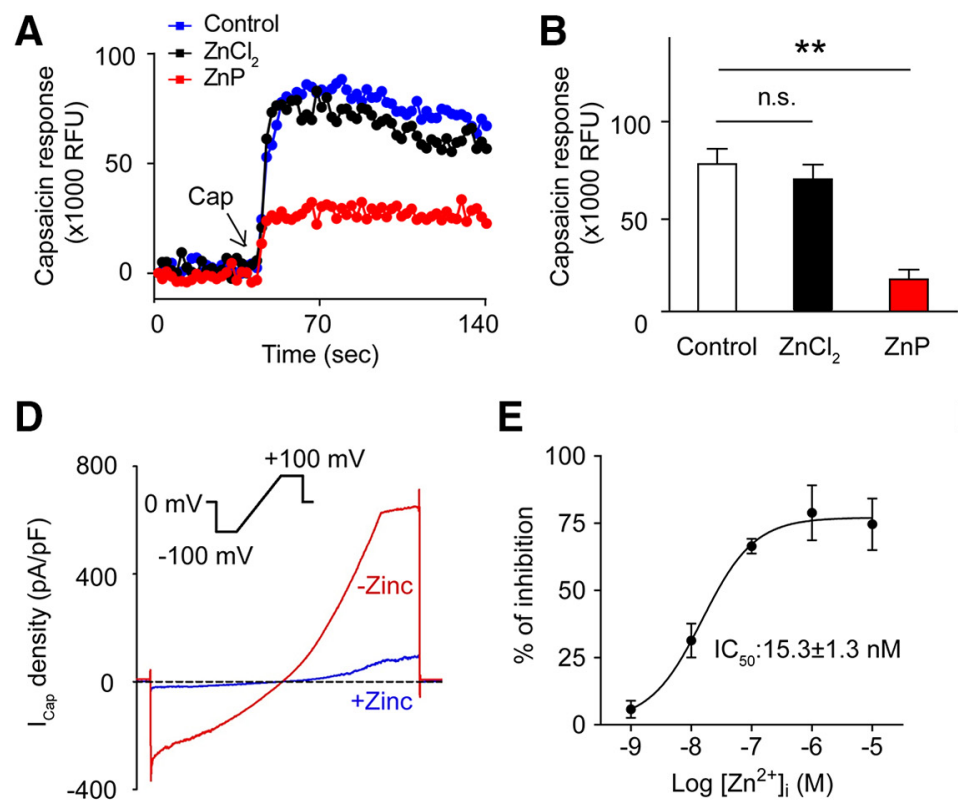

E

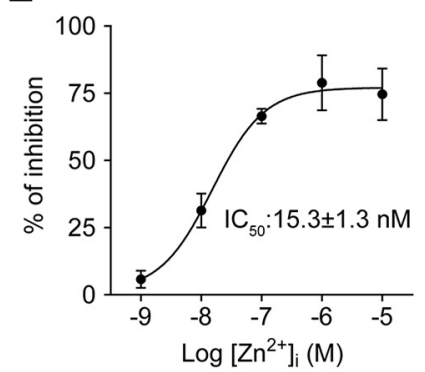

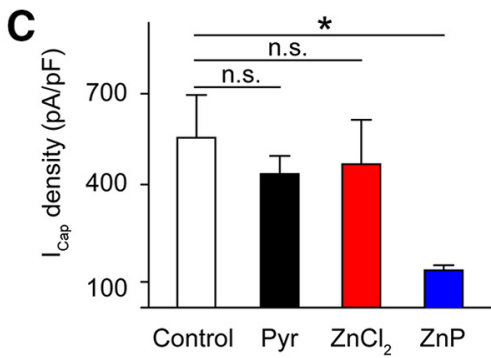

$\mathbf{F}$

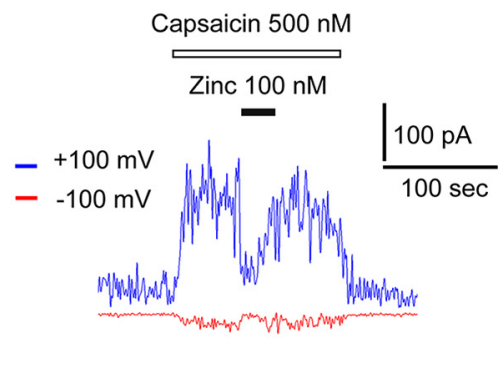

Figure 3. Intracellular, but not extracellular, zinc inhibits capsaicin-induced responses. $\boldsymbol{A}$, Representative traces showing $\left[\mathrm{Ca}^{2+}\right]_{i}$ responses induced by capsaicin in the presence of buffer (blue circle), $\mathrm{ZnCl}_{2}$ (black circle), and $\mathrm{ZnP}$ (red circle) assayed by Flexstation. $\boldsymbol{B}$, Bar graph represents the summarized data in $\boldsymbol{A}$. ${ }^{* *} p<0.01$ versus control group. n.s., Not significant versus control group (ANOVA). $n=6$ for each condition. C, Bar graph represents capsaicin-activated whole-cell current densities at the holding potential of $+100 \mathrm{mV}$ in TRPV1-expressing HEK293 cells in the presence of extracellular Pyr $(30 \mu \mathrm{m}), \mathrm{ZnCl}_{2}(30 \mu \mathrm{M})$, and $\mathrm{ZnP}(30 \mu \mathrm{m}) .{ }^{*} p<0.05$ versus control group. n.s., Not significant versus control group (ANOVA). $n=5$ cells in each group. $D$, Representative current-voltage curves of capsaicin-activated membrane currents in response to voltage ramps from $-100 \mathrm{mV}$ to $+100 \mathrm{mV}$ (insert) in the absence (red) or presence (blue) of $100 \mathrm{~nm}$ zinc in the recording pipette. $\boldsymbol{E}$, Concentration-response curve for the inhibitory effect of intracellular zinc was fitted with the logistic equation: $Y=Y_{\min }+\left(Y_{\text {max }}-Y_{\text {min }}\right) /\left(1+10^{\wedge}\left[\left(\log \mathrm{EC}_{50}-X\right) \times\right.\right.$ Hill slope)], where $Y$ is the response at a given concentration, $Y_{\max }$ and $Y_{\min }$ are the maximum and minimum response, $X$ is the logarithmic value of the concentration, and Hill slope is the slope factor of the curve. $\mathrm{EC}_{50}$ is the concentration that gives a response halfway between $Y_{\max }$ and $Y_{\min }$. $\boldsymbol{F}$, Representative traces show the capsaicin (500 nm)-activated macroscopic membrane currents from an inside-out membrane patch at holding potentials of $-100 \mathrm{mV}$ and $+100 \mathrm{mV}$; $100 \mathrm{~nm}$ zinc nearly abolished the capsaicin-activated current when applied to the inside of the membrane. Horizontal bars represent the time course of chemical applications.

$\mathrm{ZnCl}_{2}$, three populations of neurons responded differentially to subsequent applications of capsaicin: the first group of neurons had no or negligible $\left[\mathrm{Ca}^{2+}\right]_{i}$ response to both $\mathrm{ZnCl}_{2}$ and capsaicin but had a large response to $\mathrm{KCl}$ (Fig. $2 \mathrm{~A}$, black traces); the second group of neurons had no or negligible response to $\mathrm{ZnCl}_{2}$ but retained a large capsaicin response (Fig. $2 \mathrm{~A}$, blue traces); and the third group of neurons had a large $\left[\mathrm{Ca}^{2+}\right]_{i}$ response to $\mathrm{ZnCl}_{2}$ but a negligible response to capsaicin (Fig. $2 A$, red traces). These results indicate that neurons exhibiting large responses to $\mathrm{ZnCl}_{2}$ have severely attenuated capsaicin responses. Based on previous studies showing that TRPA1 coexpresses with TRPV1 (Story et al., 2003; Bautista et al., 2005) and TRPA1 mediates $\mathrm{ZnCl}_{2}$-elicited $\left[\mathrm{Ca}^{2+}\right]_{i}$ response in DRG neurons (Andersson et al., 2009; $\mathrm{Hu}$ et al., 2009), we speculated that activation of TRPA1 by $\mathrm{ZnCl}_{2}$ inhibits TRPV1 function in the same DRG neurons. Unexpectedly, neurons that responded to preapplied allyl isothiocyanate (AITC) (Fig. 2B, red traces) still retained a large capsaicin-evoked $\left[\mathrm{Ca}^{2+}\right]_{i}$ response, supporting reports that TRPA1 is expressed by a subset of TRPV1-expressing nociceptors (Story et al., 2003; Jordt et al., 2004), but activation of TRPA1 in general does not inhibit TRPV1 function. Therefore, zinc-induced inhibition of TRPV1 in DRG neurons is a unique property of zinc, separable from consequences resulting from activation of TRPA1 by other activators, such as AITC. We further examined the effect of zinc on capsaicin-induced excitation of DRG neurons using currentclamp recording. Consistent with $\mathrm{Ca}^{2+}$ imaging and behavioral results, capsaicin evoked a large membrane potential depolarization and robust action potential firing, which was significantly inhibited by pretreatment with extracellular $\mathrm{ZnCl}_{2}\left(F_{(2,18)}=\right.$
8.81, $p=0.002$; Fig. $2 C$ ). To determine whether zinc could inhibit TRPV1-mediated excitation of DRG neurons specifically innervating paws of paclitaxel-treated mice, we injected retrograde tracing dye DiI into the paws of paclitaxel-treated mice and examined the effect of $\mathrm{ZnCl}_{2}$ on capsaicin-induced excitation of the DiI-labeled DRG neurons. Indeed, $\mathrm{ZnCl}_{2}$ also severely reduced capsaicin-induced membrane depolarization of the labeled DRG neurons from mice treated with paclitaxel $\left(F_{(2,15)}=\right.$ 22.20, $p<0.0001$; Fig. $2 D$ ), suggesting that zinc likely suppresses TRPV1 function in DRG neurons innervating both skin and visceral organs (Vysotskaya et al., 2014). Moreover, $\mathrm{ZnCl}_{2}$ can inhibit TRPV1 function under normal conditions and in CIPN.

\section{Zinc acts intracellularly to inhibit TRPV1}

To further investigate the mechanism underlying zinc inhibition of TRPV1, we tested the effect of $\mathrm{ZnCl}_{2}$ on TRPV1 heterologously expressed in HEK293 cells. Unexpectedly, we did not detect an inhibitory effect of $\mathrm{ZnCl}_{2}$ on capsaicin-induced $\left[\mathrm{Ca}^{2+}\right]_{i}$ response and membrane current when $\mathrm{ZnCl}_{2}$ was applied extracellularly, suggesting that extracellular zinc does not inhibit TRPV1 function and the lack of inhibition of extracellular $\mathrm{ZnCl}_{2}$ might be due to the lack of entry route for zinc into the HEK293 cells. To test this hypothesis, we used zinc pyrithione $(\mathrm{ZnP})$, a zinc ionophore that allows zinc entry into cells (Andersson et al., 2009). Indeed, although pyrithione alone had no effect on the capsaicin-induced $\left[\mathrm{Ca}^{2+}\right]_{i}$ response, $\mathrm{ZnP}$ exhibited a strong inhibition of capsaicin response when applied to the extracellular site, suggesting that zinc indeed acts intracellularly to inhibit TRPV1 function $\left(F_{(2,15)}=\right.$ 19.73, $p<0.0001$; Fig. $3 A, B)$, which is consistent with a previous report that zinc inhibited acid-evoked TRPV1 current intracellu- 

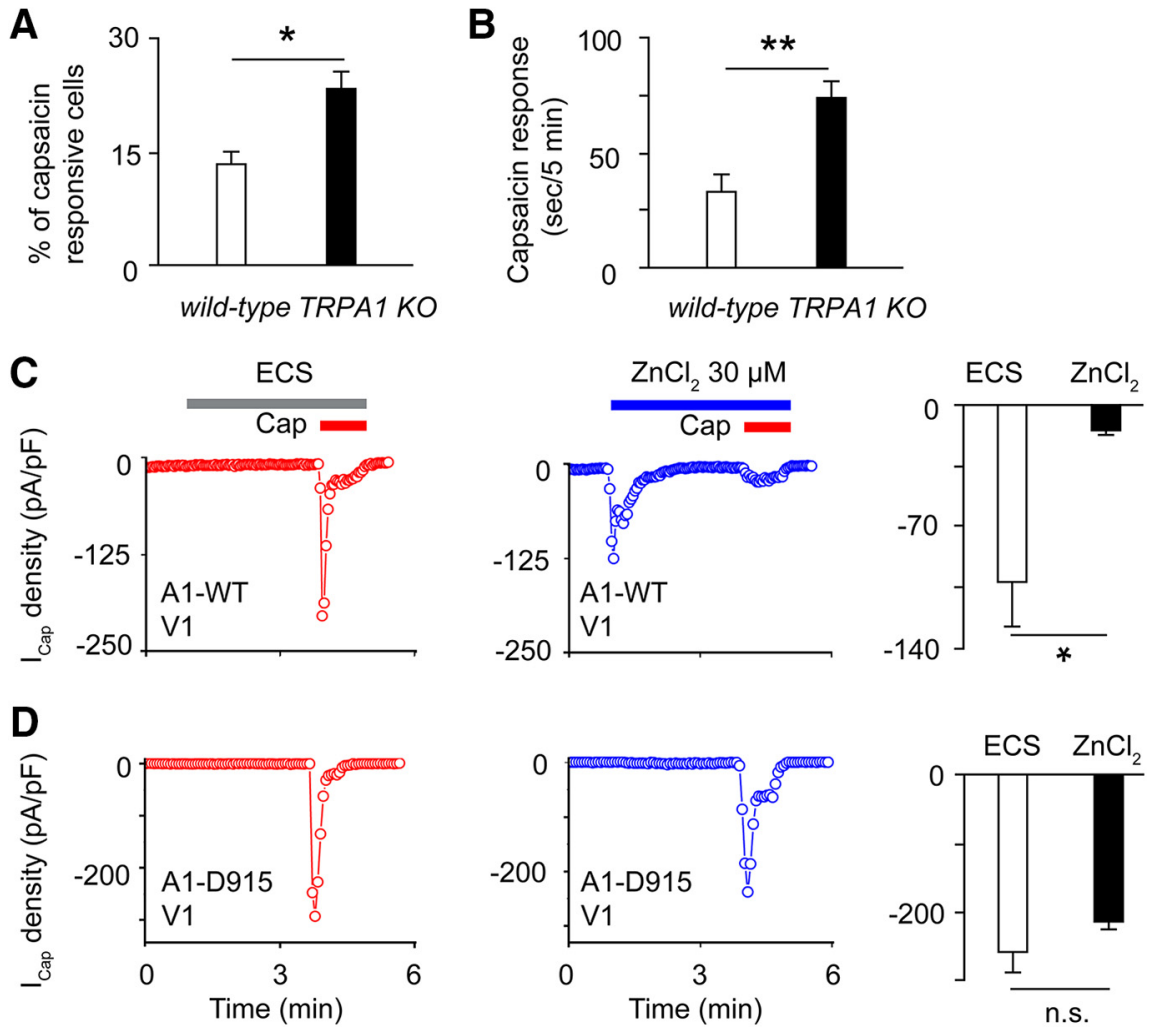

Figure 4. TRPA1 is required for the inhibitory effect of zinc on TRPV1-mediated acute responses. $\boldsymbol{A}$, Bar graph represents the percentages of wild-type and TRPA1 KO DRG neurons responding to capsaicin in the presence of extracellular zinc $(30 \mu \mathrm{M}) .{ }^{*} p<$ 0.05 versus wild-type group (Student's $t$ test). $n=5$ coverslips in each group. $B$, Bar graph represents the effects of pretreatment with zinc $(30 \mathrm{~mm}, 10 \mu \mathrm{l})$ on capsaicin $(0.5 \mu \mathrm{g}, 10 \mu \mathrm{l})$-induced nociceptive behaviors in wild-type and TRPA1 K0 mice. ${ }^{* *} p<0.01$ versus wild-type group (Student's $t$ test). $n=7$ mice for the wild-type group and $n=6$ mice for the TRPA1 K0 group. C,Capsaicin $(1 \mu \mathrm{m})$-activated inward currents in the presence of normal extracellular buffer (ECS, left) or ECS plus zinc (30 $\mu \mathrm{m}$, middle) in HEK293 cells coexpressing TRPV1 and wild-type TRPA1. Right, Summarized data. ${ }^{*} p<0.05$ versus ECS group (Student's $t$ test). $n=6$ cells in each group. $\boldsymbol{D}$, Capsaicin $(1 \mu \mathrm{M})$-activated inward currents in the presence of ECS (left) or ECS plus zinc (30 $\mu \mathrm{M}$, middle) in HEK293 cells coexpressing TRPV1 and the TRPA1 zinc permeation mutant (D915). The summarized data are shown on the right. n.S., Not significant versus ECS group (Student's $t$ test). $n=6$ cells in each group.

larly in rat vagal bronchopulmonary sensory neurons (Vysotskaya et al., 2014). This conclusion is also supported by the findings that capsaicin-activated whole-cell currents were severely reduced by application of extracellular $\mathrm{ZnP}$ but not pyrithione or $\mathrm{ZnCl}_{2}\left(F_{(3,16)}=6.05, p=0.006\right.$; Fig. 3C). To further test this hypothesis, we applied $\mathrm{ZnCl}_{2}$ (with a final free $\mathrm{Zn}^{2+}$ concentration of $100 \mathrm{~nm}$ calculated using Maxchelator program) directly to the cytoplasmic side of TRPV1-expressing HEK293 cells by recording pipette dialysis. Consistent with the $\mathrm{ZnP}$ result, intracellular $\mathrm{ZnCl}_{2}$ reduced capsaicin-activated whole-cell currents at both positive and negative membrane potentials in a concentration-dependent manner (Fig. 3D,E). The concentration-response curve of $\mathrm{Zn}^{2+}$ inhibition reveals an $\mathrm{IC}_{50}$ value of $\sim 15 \mathrm{~nm}$ (Fig. $3 E$ ). In line with these findings, when applied directly to the cytoplasmic side of the membrane, zinc inhibited capsaicin-induced macroscopic current in inside-out patches isolated from the TRPV1-expressing HEK293 cells (Fig. 3F).

TPRA1 mediates the inhibitory effect of extracellular zinc on capsaicin-induced

nociception

The finding that zinc acts intracellularly to inhibit TRPV1 raises the question about the route of zinc entry into DRG neurons. Our previous studies have identified TRPA1 as a major route for zinc entry into primary nociceptors because genetic ablation of TRPA1 function abolished the large zinc influx in DRG neurons (Hu et al., 2009). In addition, TRPA1 is selectively expressed by $\sim 50 \%$ of TRPV1-positive primary sensory nociceptors (Story et al., 2003; Jordt et al., 2004; Bautista et al., 2005). We thus asked whether TRPA1 is required for inhibition of TRPV1 in DRG neurons by extracellular zinc. To test this hypothesis, we first examined the proportion of DRG neurons responding to capsaicin in both wildtype and TRPA1 KO mice in the presence of extracellular $\mathrm{ZnCl}_{2}$. As shown in Figure $4 A$, deficiency of TRPA 1 function significantly increased the proportion of capsaicin-responsive DRG neurons in the presence of extracellular $\mathrm{ZnCl}_{2}\left(t_{(8)}=\right.$ 3.52, $p=0.023)$, suggesting that TRPA1 is involved in the inhibition of capsaicin response by extracellular $\mathrm{ZnCl}_{2}$. Consistent with this finding, zinc also exhibited significantly less inhibitory effect on capsaicin-evoked nocifensive response in the TRPA1 KO mice compared with the wild-type mice $\left(t_{(11)}=4.003, p=0.002\right.$; Fig. $4 B)$.

To further elucidate the role of TRPA1 in extracellular zinc-induced inhibition of TRPV1, we examined $\mathrm{ZnCl}_{2}$-induced inhibition of capsaicin response in HEK293 cells coexpressing TRPV1 and TRPA1. In marked contrast to the finding that capsaicin response in HEK293 cells expressing TRPV1 alone was not inhibited by extracellular $\mathrm{ZnCl}_{2}$ (Fig. 3C), capsaicininduced current was substantially inhibited by extracellular $\mathrm{ZnCl}_{2}$ in $\mathrm{HEK} 293$ cells cotransfected with TRPV1 and TRPA1 constructs $\left(t_{(10)}=3.11, p=0.023\right.$; Fig. $\left.4 C\right)$, suggesting that TRPA1 can indeed serve as an important zinc carrier mediating zinc influx for inhibition of TRPV1 function in the same cell. We further investigated whether zinc permeation mutation of TRPA1 affects the inhibitory effect of zinc on capsaicin response by coexpressing TRPV1 and mutant TRPA1-D915A, which is functional but lacks zinc permeability (Hu et al., 2009). As expected, capsaicin-induced current was not significantly inhibited by extracellular zinc in HEK293 cells expressing TRPV1 and mutant TRPA1-D915A $\left(t_{(10)}=1.366, p=0.199\right.$; Fig. $\left.4 D\right)$. Combined, these results demonstrate that TRPA1 serves as a cellular zinc entry route for the zinc inhibition of TRPV1function.

\section{Inhibition of paclitaxel-induced chronic neuropathic pain by} zinc requires zinc transporters but not TRPA1

Next, we tested whether TRPA1 is also required for zinc inhibition of paclitaxel-induced chronic neuropathic pain. To our surprise, the inhibitory effect of zinc on mechanical hypersensitivity induced by paclitaxel was not significantly different between TRPA1 KO mice and wild-type mice $\left(F_{(1,60)}=0.01, p=0.971\right.$; Fig. 5A), suggesting that TRPA1 is not a primary carrier of zinc entry into primary nociceptors to inhibit TRPV1-dependent chronic neuropathic pain induced by paclitaxel. TRPA1 is a highly desensitizing channel, especially in the presence of physiological concentrations of extracellular $\mathrm{Ca}^{2+}$ (1-3 mM) (Akopian et al., 2007). The 
A

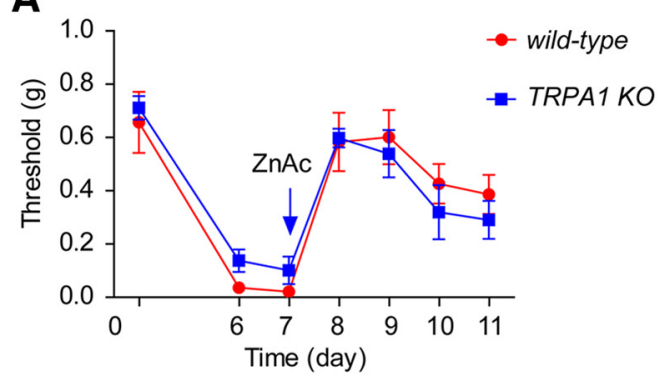

C

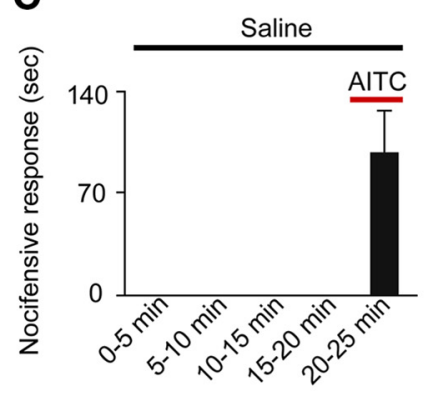

$\mathbf{F}$

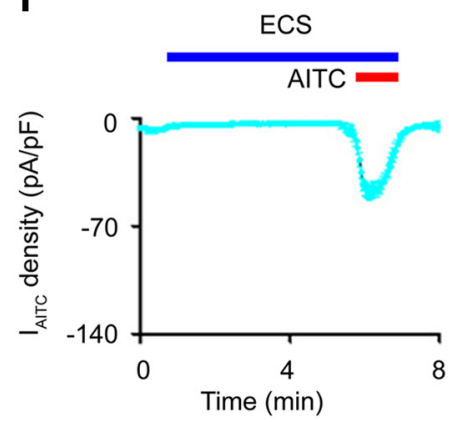

B
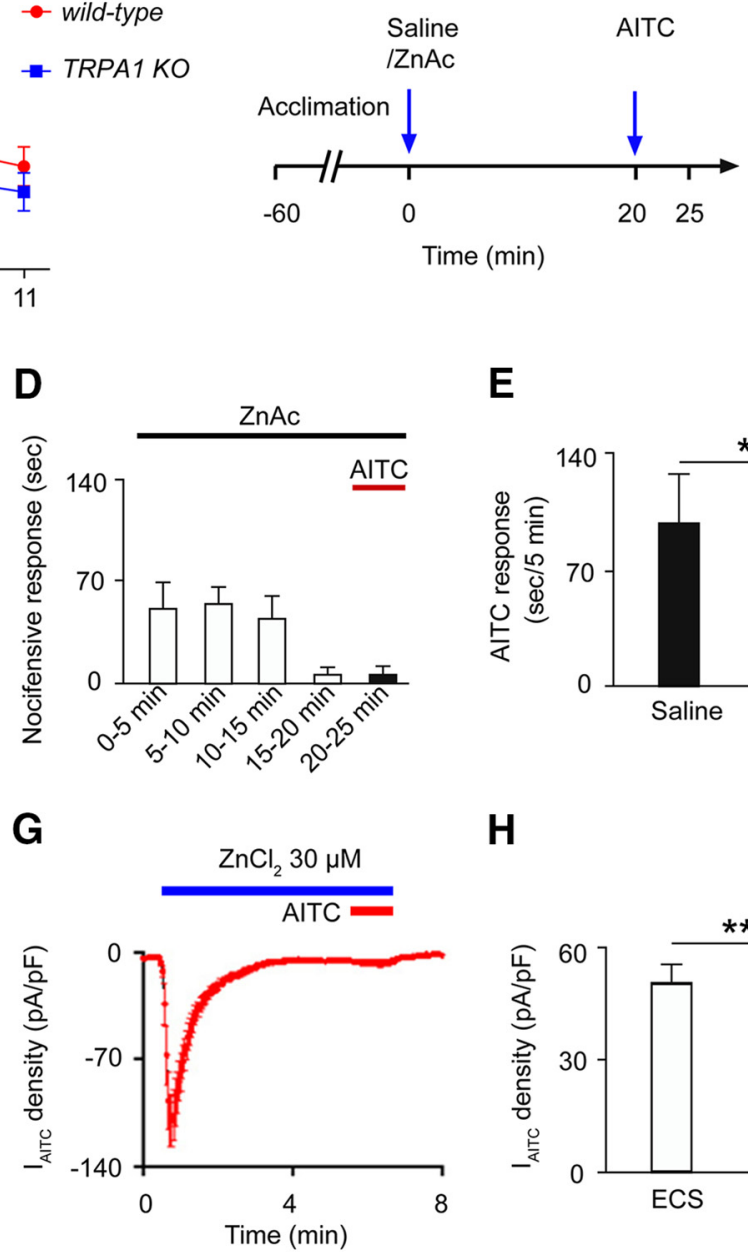

Figure 5. TRPA1 is not involved in zinc inhibition of paclitaxel-induced mechanical hypersensitivity, and zinc strongly desensitizes TRPA1-mediated current and acute nocifensive responses. $A$, Intraplantar injection of $\mathrm{ZnAc}(30 \mathrm{~mm}, 10 \mu \mathrm{l})$ produced a similar inhibition on paclitaxel-induced mechanical hypersensitivity in both wild-type and TRPA1 K0 mice. $n=6$ mice in each group. $\boldsymbol{B}$, Schematic protocol of zinc-induced inhibition of AITC ( $75 \mathrm{~mm}, 10 \mu \mathrm{l})$-elicited acute nocifensive responses. Animals were acclimated for $1 \mathrm{~h}$ before $\mathrm{ZnAc}(30 \mathrm{~mm})$ or saline administration into the paws. Twenty minutes later, AITC ( $75 \mathrm{~mm}, 10 \mu \mathrm{l}$ ) was injected into the same paws. The nocifensive responses were recorded for 5 min after AlTC administration. C, Bar graph demonstrates that AlTC elicited a robust nocifensive response in mice pretreated with saline. $D$, Intraplantar injections of $Z \mathrm{nAc}(30 \mathrm{~mm}, 10 \mu \mathrm{l})$ produced a nocifensive response that gradually desensitized within 20 min after administration. Subsequent applications of AITC ( $75 \mathrm{~mm}, 10 \mu \mathrm{l})$ did not evoke measurable nocifensive responses. $\boldsymbol{E}$, Bar chart represents AITC (75 mM, $10 \mu \mathrm{l})$-elicited nocifensive responses in mice 20 min after pretreatment with either $10 \mu$ lsaline or $Z n A c(30 \mathrm{~mm}) .{ }^{*} p<0.05$ versus saline group (Student's $t$ test). $n=5$ mice in each group. $\boldsymbol{F}-\boldsymbol{H}$, Extracellular application of zinc ( $\left.30 \mu \mathrm{m}\right)(\boldsymbol{G})$, but not ECS $(\boldsymbol{F})$, nearly abolished membrane current activated by subsequent application of AITC (100 $\mu \mathrm{m})$ in TRPA1-expressing HEK293 cells. $\boldsymbol{H}$, Summarized data from $\boldsymbol{F}$ and $\boldsymbol{G}$. ${ }^{* *} p<0.01$ versus ECS group (Student's $t$ test). $n=6$ for $\mathrm{ECS}$ and $n=5$ for $\mathrm{ZnCl}_{2}$.

fact that TRPA1 is involved in the zinc inhibition of capsaicininduced acute nociception, but not paclitaxel-induced TRPV1dependent chronic neuropathic pain, raises the possibility that TRPA1 might desensitize over time following initial activation in the presence of sustained high levels of extracellular zinc, making it unavailable for zinc influx. To test this hypothesis, we examined the effect of zinc on AITC-induced nocifensive behaviors. Consistent with our previous study (Hu et al., 2009), intraplantar injections of $\mathrm{ZnAc}$ elicited robust nocifensive behaviors lasting for $\sim 15 \mathrm{~min}$. However, subsequent application of AITC failed to evoke obvious nocifensive behaviors, which is in marked contrast to the robust nociceptive responses induced by AITC in the absence of zinc $\left(t_{(8)}=3.186, p=0.013\right.$; Fig. $\left.5 B-E\right)$. Similarly, AITCinduced membrane current in TRPA1-expresing HEK293 cells was also greatly attenuated by the preapplied zinc, which initially activated a large membrane current $\left(t_{(9)}=3.716, p=0.005\right.$; Fig. $\left.5 F-H\right)$. These results support that zinc-elicited TRPA1 desensitization might account for the ineffectiveness of TRPA1 in mediating zinc inhi- bition of TRPV1 in the chronic neuropathic pain induced by paclitaxel.

In addition to TRPA1, ZIPs also serve as important entry pathways for extracellular zinc in mammalian cells (Cousins et al., 2006; Kambe et al., 2015). We thus determined the expression of ZIPs in mouse DRG using quantitative RT-PCR. Among 14 known ZIPs, ZIP3, ZIP6, and ZIP7 were the most abundant isoforms in mouse DRG (Fig. 6A). We therefore knocked down the expression of these three ZIPs through intrathecal administration of siRNAs and then examined the inhibitory effect of zinc on paclitaxel-induced mechanical hypersensitivity. Strikingly, zincinduced inhibitory effect on paclitaxel-induced mechanical hypersensitivity was significantly reduced in mice treated with siRNAs against ZIP3, ZIP6, and ZIP7 compared with mice treated with nontargeting control siRNA only $\left(F_{(1,48)}=45.20, p<0.0001\right.$; Fig. $\left.6 B\right)$, suggesting that these three ZIPs are significantly involved in zinc inhibition of paclitaxel-induced chronic neuropathic pain. Consistent with behavioral studies, the inhibitory effect of zinc on 

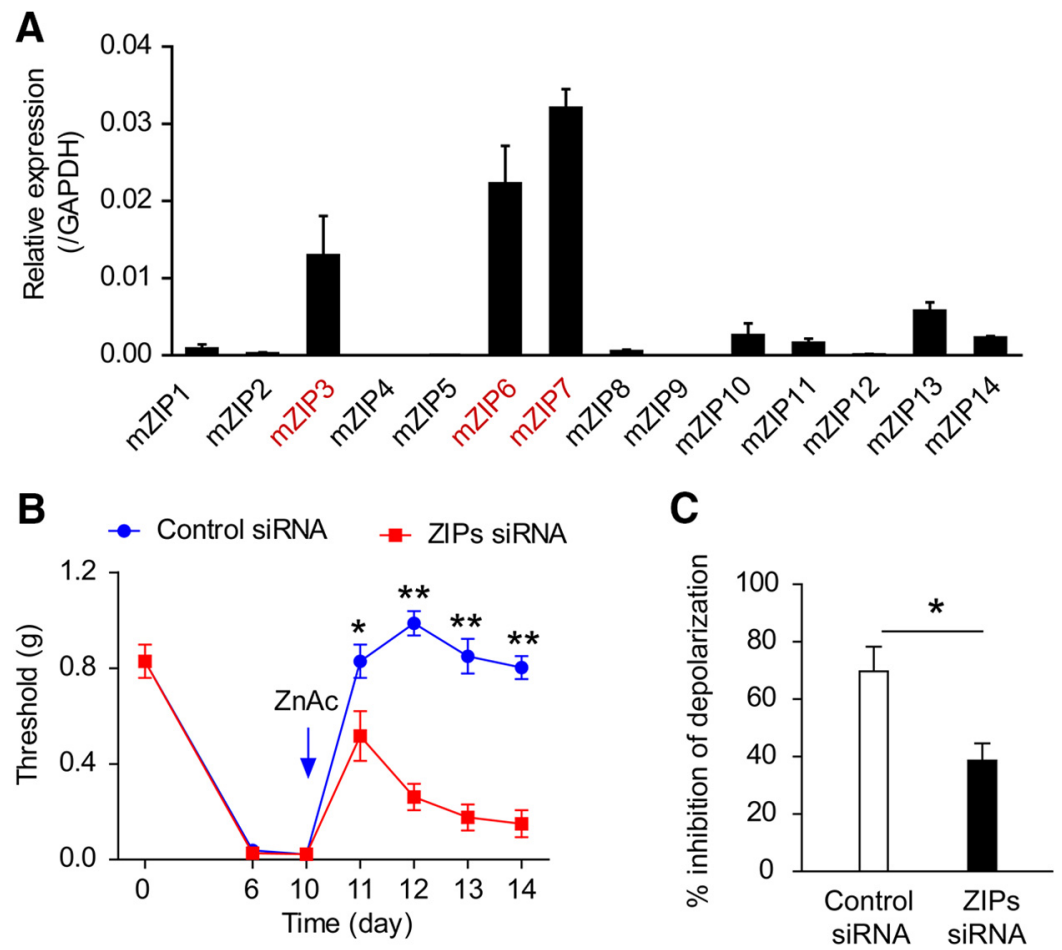

Figure 6. Inhibition of paclitaxel-induced mechanical hypersensitivity by zinc requires ZIPs. $\boldsymbol{A}$, Relative expression of 14 ZIP zinc transporters in mouse DRG. The most abundantly expressed three ZIPs are highlighted in red. $\boldsymbol{B}$, Intrathecal application of siRNAs against ZIP3, ZIP6, and ZIP7, but not control siRNA, severely reduced the inhibitory effect of ZnAc on paclitaxel-induced mechanical hypersensitivity. ${ }^{*} p<0.05$ versus control siRNA group (repeated-measures ANOVA). ${ }^{* *} p<0.01$ versus control siRNA group (repeated-measures ANOVA). $n=5$ mice for each group. $C$, Bar chart demonstrates that inhibition of capsaicin-evoked membrane depolarization by zinc in DRG neurons was significantly attenuated by intrathecally applied siRNAs against ZIP3, ZIP6, and ZIP7 compared with that in DRG neurons treated with control siRNA. ${ }^{*} p<0.05$ versus control siRNA group (Student'st test). $n=7$ cells for each group.

capsaicin-induced membrane depolarization was also significantly attenuated in DRG neurons isolated from mice treated with siRNAs against selected three ZIPs compared with those from mice treated with nontargeting control siRNA $\left(t_{(12)}=\right.$ 3.066, $p=0.012$; Fig. $6 C$ ). These data strongly support that ZIP3, ZIP6, and ZIP7, but not TRPA1, are required for zinc-induced inhibition on chronic neuropathic pain produced by paclitaxel treatment.

\section{Discussion}

CIPN is a common consequence of chemotherapy that is neither well understood nor effectively treated. It affects $>50 \%$ of cancer patients treated with commonly used classes of chemotherapy drugs, and has a significant negative impact on treatment outcome and patient's quality of life. Therefore, effective and safe treatment strategies are urgently needed to reduce the often persistent and debilitating effects of painful CIPN. In this study, we have provided evidence that locally injected zinc is effective in reducing mechanical hypersensitivity induced by paclitaxel treatment in a TRPV1-dependent manner, having little effect on the contralateral paws. We further show that extracellular zinc is a potent inhibitor of TRPV1 expressed in DRG neurons both under normal conditions and in CIPN and suppresses capsaicin-elicited acute nocifensive responses. Zinc-induced inhibition of TRPV1 function requires the presence of TRPA1 that facilitates zinc influx, and genetic ablation of TRPA1 function severely reduces the inhibitory effect of zinc on capsaicin responses both in vitro and in vivo. Unexpectedly, we show that inhibition of paclitaxel-induced neuropathic pain by zinc is not mediated by TRPA1, which might result from the desensitization property of the channel. Instead, zinc transporters, especially ZIP3, ZIP6, and ZIP7, are critically involved in the zinc inhibition of mechanical hypersensitivity induced by paclitaxel treatment. Our results suggest that zinc suppresses both acute nociception and chemotherapy-induced chronic neuropathic pain through inhibiting TRPV1, although distinct zinc entry routes are required under acute and chronic settings.

Zinc has been widely used as an antiinflammatory and antiarthritic agent (Cousins and Swerdel, 1985; Whitehouse et al., 1990). Several lines of evidence suggest that exogenously applied zinc has an antihyperalgesic effect in a number of inflammatory and neuropathic pain model systems (Safieh-Garabedian et al., 1996; Larson and Kitto, 1999; Liu et al., 1999; Nozaki et al., 2011). Although the mechanisms underlying zinc modulation of pain responses are complex, zinc has been shown to regulate functions of many pain-related ion channels, including acidsensing ion channels (Jiang et al., 2011), TRPV1 (Vysotskaya et al., 2014), and NMDA receptors (Nozaki et al., 2011; Peralta and Huidobro-Toro, 2016). We and others have previously shown that zinc activates and permeates the paininitiating TRPA1 channels and elicits a nociceptive response (Andersson et al., 2009; Hu et al., 2009; Vysotskaya et al., 2014). Nevertheless, in the present study, we showed that zinc inhibits TRPV1 and suppresses capsaicin-induced excitation of DRG neurons and nociceptive responses, which requires the expression of TRPA1. Several lines of evidence have demonstrated mutual modulation between TRPV1 and TRPA1, which are coexpressed in primary nociceptors (Staruschenko et al., 2010; Spahn et al., 2014; Weng et al., 2015). However, TRPA1 agonist AITC did not inhibit capsaicin responses, suggesting that the inhibitory effect of zinc on TRPV1 is an intrinsic property of zinc, separable from other TRPA1 activators. This is further confirmed by the finding that zinc permeation mutation of TRPA1 abolished the inhibitory effect of zinc on TRPV1. These data indicate that TRPA1 serves as the entry route for extracellular zinc to gain access to the intracellular side of the cell and suppress TRPV1. Furthermore, zinc application markedly desensitizes TRPA1-mediated membrane currents in heterologous cells and AITC-elicited nocifensive responses in vivo. These findings might provide distinct mechanisms underlying the antihyperalgesic effect of zinc through inhibition of both TRPA1 and TRPV1.

Although the role of TRPV 1 in the pathogenesis of chemotherapyinduced chronic neuropathic pain is still largely unknown, accumulating evidence suggests that both expression and function of TRPV1 are increased upon treatment with commonly used chemotherapy drugs. For instance, TRPV1 expression in both skin and DRG is increased in rats treated with paclitaxel (Hara et al., 2013). Consistent with enhanced expression, treatment with oxaliplatin increases intracellular cAMP and sensitizes responses elicited by capsaicin and icilin in DRG neurons (Anand et al., 2010). Importantly, many exogenous and endogenous TRPV1 
inhibitors efficiently reduce chemotherapy-induced neuropathic pain through either direct inhibition of TRPV1 or indirect inhibition of TRPV1 sensitization by signal transduction metabolites (Sałat et al., 2014; Gao et al., 2016; Sisignano et al., 2016). Interestingly, although TRPV1 antagonists have been shown to reduce neuropathic pain (Chen et al., 2011; Li et al., 2015), we found that the mechanical hypersensitivity in wild-type mice was not significantly different from the TRPV1 KO mice when both were treated with paclitaxel, suggesting that there might be a genetic redundancy for paclitaxel-induced pain response in mice.

On the other hand, exogenously applied zinc markedly reduced mechanical hypersensitivity produced by paclitaxel treatment in a TRPV1-dependent manner. Unexpectedly, although the inhibitory effect of zinc on capsaicin-induced response was completely abolished by the absence of TRPA1 or in the presence of the zinc permeation mutation of TRPA1 in heterologous cells, zinc still exhibited inhibitory effect on paclitaxel-induced neuropathic pain in TRPA1 $\mathrm{KO}$ mice, indicating that TRPA1 function is not essential or unavailable for the zinc entry under chronic settings. These data are consistent with the findings that zinc desensitizes TRPA 1 function both in vitro and in vivo, and suggest that alternative zinc entry routes may also exist in DRG neurons in vivo, such as a large number of zinc transporters, which could mediate the influx of zinc into nociceptors (Cousins et al., 2006). Indeed, we detected abundant expression of ZIP3, ZIP6, and ZIP7 in DRG, and administration of siRNAs against these three ZIPs markedly reduced the inhibitory effect of zinc on paclitaxelinduced mechanical hypersensitivity. Our results suggest that ZIPs are critically involved in zinc entry into nociceptors, which leads to inhibition of TRPV1-dependent neuropathic pain produced by paclitaxel treatment.

Although TRPV1 is also reported to express centrally in the thalamus, locus ceruleus, periaqueductal gray, cortex, and spinal cord (Steenland et al., 2006; Kim et al., 2012), recent studies using TRPV1 reporter mice have shown that TRPV1 is primarily expressed by primary nociceptors with minimal expression in the CNS that is restricted to the area around the caudal hypothalamus (Cavanaugh et al., 2011a, b). Our study demonstrates that zinc inhibits TRPV1-dependent acute and chronic pain responses in primary nociceptors, revealing a novel peripheral mechanism for zinc-mediated analgesic effect. Locally injected zinc could produce a sustained inhibition of TRPV1 and reduce chemotherapy-induced neuropathic pain for $>4 \mathrm{~d}$ after one single injection. Interestingly, CIPN generally develops with a symmetric, distal, and lengthdependent "glove and stocking" distribution affecting predominantly the feet and hands at the extremities. Thus, administration of zinc to localized areas associated with pain might be an effective and safe approach to treat pain without causing systemic side effects, considering that zinc plays a critical role in regulating neurotransmissions in the CNS (Jo et al., 2000; Smart et al., 2004; Wall, 2005; Nakashima and Dyck, 2009; Marger et al., 2014).

\section{References}

Addington J, Freimer M (2016) Chemotherapy-induced peripheral neuropathy: an update on the current understanding. F1000Res 5:1466. CrossRef Medline

Akopian AN, Ruparel NB, Jeske NA, Hargreaves KM (2007) Transient receptor potential TRPA1 channel desensitization in sensory neurons is agonist dependent and regulated by TRPV1-directed internalization. J Physiol 583:175-193. CrossRef Medline

Anand U, Otto WR, Anand P (2010) Sensitization of capsaicin and icilin responses in oxaliplatin treated adult rat DRG neurons. Mol Pain 6:82. CrossRef Medline

Andersson DA, Gentry C, Moss S, Bevan S (2009) Clioquinol and pyri- thione activate TRPA1 by increasing intracellular $\mathrm{Zn}^{2+}$. Proc Natl Acad Sci U S A 106:8374-8379. CrossRef Medline

Bautista DM, Movahed P, Hinman A, Axelsson HE, Sterner O, Högestätt ED, Julius D, Jordt SE, Zygmunt PM (2005) Pungent products from garlic activate the sensory ion channel TRPA1. Proc Natl Acad Sci U S A 102: 12248-12252. CrossRef Medline

Bautista DM, Jordt SE, Nikai T, Tsuruda PR, Read AJ, Poblete J, Yamoah EN, Basbaum AI, Julius D (2006) TRPAl mediates the inflammatory actions of environmental irritants and proalgesic agents. Cell 124:1269-1282. CrossRef Medline

Boyette-Davis JA, Walters ET, Dougherty PM (2015) Mechanisms involved in the development of chemotherapy-induced neuropathy. Pain Manag 5:285-296. CrossRef Medline

Caterina MJ, Leffler A, Malmberg AB, Martin WJ, Trafton J, Petersen-Zeitz KR, Koltzenburg M, Basbaum AI, Julius D (2000) Impaired nociception and pain sensation in mice lacking the capsaicin receptor. Science 288 : 306-313. CrossRef Medline

Cavanaugh DJ, Chesler AT, Bráz JM, Shah NM, Julius D, Basbaum AI (2011a) Restriction of transient receptor potential vanilloid-1 to the peptidergic subset of primary afferent neurons follows its developmental downregulation in nonpeptidergic neurons. J Neurosci 31:10119-10127. CrossRef Medline

Cavanaugh DJ, Chesler AT, Jackson AC, Sigal YM, Yamanaka H, Grant R, O'Donnell D, Nicoll RA, Shah NM, Julius D, Basbaum AI (2011b) Trpvl reporter mice reveal highly restricted brain distribution and functional expression in arteriolar smooth muscle cells. J Neurosci 31:50675077. CrossRef Medline

Chen Y, Yang C, Wang ZJ (2011) Proteinase-activated receptor 2 sensitizes transient receptor potential vanilloid 1 , transient receptor potential vanilloid 4, and transient receptor potential ankyrin 1 in paclitaxel-induced neuropathic pain. Neuroscience 193:440-451. CrossRef Medline

Cousins RJ, Swerdel MR (1985) Ceruloplasmin and metallothionein induction by zinc and 13-cis-retinoic acid in rats with adjuvant inflammation. Proc Soc Exp Biol Med 179:168-172. CrossRef Medline

Cousins RJ, Liuzzi JP, Lichten LA (2006) Mammalian zinc transport, trafficking, and signals. J Biol Chem 281:24085-24089. CrossRef Medline

Cruz-Orengo L, Dhaka A, Heuermann RJ, Young TJ, Montana MC, Cavanaugh EJ, Kim D, Story GM (2008) Cutaneous nociception evoked by 15-delta PGJ2 via activation of ion channel TRPA1. Mol Pain 4:30. CrossRef Medline

Gao W, Zan Y, Wang ZJ, Hu XY, Huang F (2016) Quercetin ameliorates paclitaxel-induced neuropathic pain by stabilizing mast cells, and subsequently blocking PKCepsilon-dependent activation of TRPV1. Acta Pharmacol Sin 37:1166-1177. CrossRef Medline

Hara T, Chiba T, Abe K, Makabe A, Ikeno S, Kawakami K, Utsunomiya I, Hama T, Taguchi K (2013) Effect of paclitaxel on transient receptor potential vanilloid 1 in rat dorsal root ganglion. Pain 154:882-889. CrossRef Medline

Hershman DL, Lacchetti C, Dworkin RH, Lavoie Smith EM, Bleeker J, Cavaletti G, Chauhan C, Gavin P, Lavino A, Lustberg MB, Paice J, Schneider B, Smith ML, Smith T, Terstriep S, Wagner-Johnston N, Bak K, Loprinzi CL (2014) Prevention and management of chemotherapy-induced peripheral neuropathy in survivors of adult cancers: American Society of Clinical Oncology clinical practice guideline. J Clin Oncol 32:1941-1967. CrossRef Medline

Hu H, Bandell M, Petrus MJ, Zhu MX, Patapoutian A (2009) Zinc activates damage-sensing TRPA1 ion channels. Nat Chem Biol 5:183-190. CrossRef Medline

Huang SM, Lee H, Chung MK, Park U, Yu YY, Bradshaw HB, Coulombe PA, Walker JM, Caterina MJ (2008) Overexpressed transient receptor potential vanilloid 3 ion channels in skin keratinocytes modulate pain sensitivity via prostaglandin E2. J Neurosci 28:13727-13737. CrossRef Medline

Izumi H, Mori H, Uchiyama T, Kuwazuru S, Ozima Y, Nakamura I, Taguchi S (1995) Sensitization of nociceptive C-fibers in zinc-deficient rats. Am J Physiol Regul Integr Comp Physiol 268:R1423-R1428. Medline

Jiang Q, Inoue K, Wu X, Papasian CJ, Wang JQ, Xiong ZG, Chu XP (2011) Cysteine 149 in the extracellular finger domain of acid-sensing ion channel $1 \mathrm{~b}$ subunit is critical for zinc-mediated inhibition. Neuroscience 193: 89-99. CrossRef Medline

Jo SM, Danscher G, Schrøder HD, Won MH, Cole TB (2000) Zinc-enriched (ZEN) terminals in mouse spinal cord: immunohistochemistry and autometallography. Brain Res 870:163-169. CrossRef Medline 
Jo SM, Danscher G, Schroder HD, Suh SW (2008) Depletion of vesicular zinc in dorsal horn of spinal cord causes increased neuropathic pain in mice. Biometals 21:151-158. CrossRef Medline

Jordt SE, Bautista DM, Chuang HH, McKemy DD, Zygmunt PM, Högestätt ED, Meng ID, Julius D (2004) Mustard oils and cannabinoids excite sensory nerve fibres through the TRP channel ANKTM1. Nature 427: 260-265. CrossRef Medline

Kambe T, Tsuji T, Hashimoto A, Itsumura N (2015) The physiological, biochemical, and molecular roles of zinc transporters in zinc homeostasis and metabolism. Physiol Rev 95:749-784. CrossRef Medline

Kim YH, Back SK, Davies AJ, Jeong H, Jo HJ, Chung G, Na HS, Bae YC, Kim SJ, Kim JS, Jung SJ, Oh SB (2012) TRPV1 in GABAergic interneurons mediates neuropathic mechanical allodynia and disinhibition of the nociceptive circuitry in the spinal cord. Neuron 74:640-647. CrossRef Medline

Koeppen AH, Kuntzsch EC, Bjork ST, Ramirez RL, Mazurkiewicz JE, Feustel PJ (2013) Friedreich ataxia: metal dysmetabolism in dorsal root ganglia. Acta Neuropathol Commun 1:26. CrossRef Medline

Lansdown AB, Mirastschijski U, Stubbs N, Scanlon E, Agren MS (2007) Zinc in wound healing: theoretical, experimental, and clinical aspects. Wound Repair Regen 15:2-16. CrossRef Medline

Larson AA, Kitto KF (1999) Chelation of zinc in the extracellular area of the spinal cord, using ethylenediaminetetraacetic acid disodium-calcium salt or dipicolinic acid, inhibits the antinociceptive effect of capsaicin in adult mice. J Pharmacol Exp Ther 288:759-765. Medline

Lee H, Iida T, Mizuno A, Suzuki M, Caterina MJ (2005) Altered thermal selection behavior in mice lacking transient receptor potential vanilloid 4 . J Neurosci 25:1304-1310. CrossRef Medline

Li Y, Adamek P, Zhang H, Tatsui CE, Rhines LD, Mrozkova P, Li Q, Kosturakis AK, Cassidy RM, Harrison DS, Cata JP, Sapire K, Zhang H, KennamerChapman RM, Jawad AB, Ghetti A, Yan J, Palecek J, Dougherty PM (2015) The cancer chemotherapeutic paclitaxel increases human and rodent sensory neuron responses to TRPV1 by activation of TLR4. J Neurosci 35:13487-13500. CrossRef Medline

Liu T, Walker JS, Tracey DJ (1999) Zinc alleviates thermal hyperalgesia due to partial nerve injury. Neuroreport 10:1619-1623. CrossRef Medline

Luo J, Zhu Y, Zhu MX, Hu H (2011) Cell-based calcium assay for medium to high throughput screening of TRP channel functions using FlexStation 3. J Vis Exp 54:e3149. CrossRef Medline

Marger L, Schubert CR, Bertrand D (2014) Zinc: an underappreciated modulatory factor of brain function. Biochem Pharmacol 91:426-435. CrossRef Medline

Matsumoto M, Inoue M, Hald A, Xie W, Ueda H (2006) Inhibition of paclitaxel-induced A-fiber hypersensitization by gabapentin. J Pharmacol Exp Ther 318:735-740. CrossRef Medline

McGrath JC, Drummond GB, McLachlan EM, Kilkenny C, Wainwright CL (2010) Guidelines for reporting experiments involving animals: the ARRIVE guidelines. Br J Pharmacol 160:1573-1576. CrossRef Medline

Miltenburg NC, Boogerd W (2014) Chemotherapy-induced neuropathy: a comprehensive survey. Cancer Treat Rev 40:872-882. CrossRef Medline

Nakashima AS, Dyck RH (2009) Zinc and cortical plasticity. Brain Res Rev 59:347-373. CrossRef Medline

Nozaki C, Vergnano AM, Filliol D, Ouagazzal AM, Le Goff A, Carvalho S, Reiss D, Gaveriaux-Ruff C, Neyton J, Paoletti P, Kieffer BL (2011) Zinc alleviates pain through high-affinity binding to the NMDA receptor NR2A subunit. Nat Neurosci 14:1017-1022. CrossRef Medline

Pastorfide GB, Gorgonio NM, Ganzon AR, Alberto RM (1989) Zinc chloride spray-magnesium hydroxide ointment dual topical regimen in the treatment of obstetric and gynecologic incisional wounds. Clin Ther 11: 258-263. Medline

Peralta FA, Huidobro-Toro JP (2016) Zinc as allosteric ion channel modu- lator: ionotropic receptors as metalloproteins. Int J Mol Sci 17:e1059. CrossRef Medline

Safieh-Garabedian B, Poole S, Allchorne A, Kanaan S, Saade N, Woolf CJ (1996) Zinc reduces the hyperalgesia and upregulation of NGF and IL-1 beta produced by peripheral inflammation in the rat. Neuropharmacology 35:599-603. CrossRef Medline

Sałat K, Cios A, Wyska E, Sałat R, Mogilski S, Filipek B, Więckowski K, Malawska B (2014) Antiallodynic and antihyperalgesic activity of 3-[4(3-trifluoromethyl-phenyl)-piperazin-1-yl]-dihydrofuran-2-one compared to pregabalin in chemotherapy-induced neuropathic pain in mice. Pharmacol Biochem Behav 122:173-181. CrossRef Medline

Sisignano M, Angioni C, Park CK, Meyer Dos Santos S, Jordan H, Kuzikov M, Liu D, Zinn S, Hohman SW, Schreiber Y, Zimmer B, Schmidt M, Lu R, Suo J, Zhang DD, Schäfer SM, Hofmann M, Yekkirala AS, de Bruin N, Parnham MJ, et al. (2016) Targeting CYP2J to reduce paclitaxel-induced peripheral neuropathic pain. Proc Natl Acad Sci U S A 113:12544-12549. CrossRef Medline

Smart TG, Hosie AM, Miller PS (2004) $\mathrm{Zn}^{2+}$ ions: modulators of excitatory and inhibitory synaptic activity. Neuroscientist 10:432-442. CrossRef Medline

Spahn V, Stein C, Zöllner C (2014) Modulation of transient receptor vanilloid 1 activity by transient receptor potential ankyrin 1 . Mol Pharmacol 85:335-344. CrossRef Medline

Staruschenko A, Jeske NA, Akopian AN (2010) Contribution of TRPV1TRPAl interaction to the single channel properties of the TRPA1 channel. J Biol Chem 285:15167-15177. CrossRef Medline

Steenland HW, Ko SW, Wu LJ, Zhuo M (2006) Hot receptors in the brain. Mol Pain 2:34. CrossRef Medline

Story GM, Peier AM, Reeve AJ, Eid SR, Mosbacher J, Hricik TR, Earley TJ, Hergarden AC, Andersson DA, Hwang SW, McIntyre P, Jegla T, Bevan S, Patapoutian A (2003) ANKTM1, a TRP-like channel expressed in nociceptive neurons, is activated by cold temperatures. Cell 112:819-829. CrossRef Medline

Velázquez RA, Cai YJ, Shi Q, Larson AA (1999) The distribution of zinc selenite and expression of metallothionein-III mRNA in the spinal cord and dorsal root ganglia of the rat suggest a role for zinc in sensory transmission. J Neurosci 19:2288-2300. Medline

Vysotskaya ZV, Moss CR 2nd, Gu Q (2014) Differential regulation of ASICs and TRPV1 by zinc in rat bronchopulmonary sensory neurons. Lung 192:927-934. CrossRef Medline

Wall MJ (2005) A role for zinc in cerebellar synaptic transmission? Cerebellum 4:224-229. CrossRef Medline

Weng HJ, Patel KN, Jeske NA, Bierbower SM, Zou W, Tiwari V, Zheng Q, Tang Z, Mo GC, Wang Y, Geng Y, Zhang J, Guan Y, Akopian AN, Dong X (2015) Tmem100 is a regulator of TRPA1-TRPV1 complex and contributes to persistent pain. Neuron 85:833-846. CrossRef Medline

Whitehouse MW, Rainsford KD, Taylor RM, Vernon-Roberts B (1990) Zinc monoglycerolate: a slow-release source of zinc with antiarthritic activity in rats. Agents Actions 31:47-58. CrossRef Medline

Xu Q, Zhang XM, Duan KZ, Gu XY, Han M, Liu BL, Zhao ZQ, Zhang YQ (2013) Peripheral TGF-beta 1 signaling is a critical event in bone cancerinduced hyperalgesia in rodents. J Neurosci 33:19099-19111. CrossRef Medline

Yin S, Luo J, Qian A, Du J, Yang Q, Zhou S, Yu W, Du G, Clark RB, Walters ET, Carlton SM, Hu H (2013) Retinoids activate the irritant receptor TRPV1 and produce sensory hypersensitivity. J Clin Invest 123:39413951. CrossRef Medline

Zekavat OR, Karimi MY, Amanat A, Alipour F (2015) A randomised controlled trial of oral zinc sulphate for primary dysmenorrhoea in adolescent females. Aust N Z J Obstet Gynaecol 55:369-373. CrossRef Medline 